\title{
結晶化したポリ乳酸のタフネス
}

\author{
伊 藤 公 ${ }^{* 1} \cdot$ 阿 部 聡 美*2 石 川 優*2
}

\section{Toughness of Crystallized Polylactic Acid}

\begin{abstract}
Ito, Masakazu*1/Abe, Satomi*2/Ishikawa, Masaru*2
The effect of crystallization due to addition of nucleus agent or the annealing on the toughness of polylactic acid (PLA) blended with acrylic elastomer was examined. It was found that heat-resistance is improved by the increase of crystallinity, but toughness is decreased.

The effect of crystallization on the toughness of PLA modified with acrylic elastomer depended on the condition of crystallization. It was found that the modified PLA crystallized by annealing is excellent in toughness in comparison with the modified PLA crystallized by the addition of nucleus agent. It was pointed out that this difference of toughness due to the condition of crystallization can be understood from the change of orientation hardening.
\end{abstract}

Key words : polylactic acid/acrylic elastomer/toughness/crystallization/orientation hardening

\section{1. 緒言}

植物由来のポリ乳酸樹脂（PLA）は，化石燃料の節約 および地球温暖化の抑制ができる環境に優しい材料として, 今後の成長が期待されている ${ }^{1)}$ ） . しかしながら, 成形時 の熱安定性, 成形品の種々の環境下での耐久性に劣り，ま た低いガラス転移温度に由来して耐熱温度も低い。これら の特性は信頼性を必要とする構造材にPLA を用いること への障害となっている。

高分子材料の破壊は, 塑性変形によって形成されるフィ ブリルを切断する応力が負荷された時に起きることが，著 者を含めた研究者により指摘されている ${ }^{4), 5}$.

高分子材料の成形品に発生する応力は, 成形品の形状, 境界条件に大きく依存する。一軸引張りでは降伏後に大き く塑性変形するが, 変形部にかかる応力がハードニングに よりフィブリルの強度を超えたときに破壊は起こる．この ような破壊は延性破壊と呼ばれている。一方，切欠きのよ うな先端半径の小さい角のある成形品では, 負荷により成

*1 三菱レイヨン(株) 中央技術研究所

Mitsubishi Rayon co., LTD. Corporate Research Laboratories 大竹市御幸町 20-1（

Otake, Hiroshima, 739-0693 Japan

*2 山形大学大学院 理工学研究科

Yamagata University Faculty of Engineering 米沢市城南 4-3-16（ ( 924-0838）

Jonan, Yonezawa, Yamagata, 992-8510 Japan 2009.5.29 受理
型品の角で容易に塑性変形が起こり，それに原因する塑性 拘束による応力集中により小さな変位で高い膨張応力が塑 性領域の先端に形成される ${ }^{6,7)}$. この膨張応力によりボイ ドが形成され，その後ボイド間の塑性変形により形成され たフィブリルに負荷される応力がその強度に到達すること により破壊が起きる。この破壊は小さな変位で極めて不安 定に起こり，脆性破壊と呼ばれている。

市販の分子量の PLA ではフィブリル強度が降伏応力に 近いので，一軸引張試験においても，降伏と同時にクレイ ズが形成され脆性破壊に至る。このようなPLAのタフネ スの向上は，他の高分子材料と同様に適当なエラストマー 添加により向上出来ることは良く知られている．著者らは アクリル系エラストマーのブレンドによるタフニングにお いて，その加工段階で PLA の分子量の低下がタフネスの 向上の効率を低下させることを指摘し，分解抑止剂を用い ることによりアクリル系エラストマーのブレンドによりタ フネスが向上されたポリカーボネート（PC）より優れた タフネスが実現できることを示しだ8).

PLA のタフネスはエラストマーのブレンドにより構造 材料としての実用的な值に向上することは可能であるが, その熱変形温度はPLAの低いガラス転移温度に由来して 低く, 家電, 自動車を対照とした構造材料には不向きであ る. PLA は適当な核剂の添加により, 結晶化が進行する ことが知られている. 結晶化は熱変形温度の向上を期待さ せる ${ }^{9)}$.

本研究では核剤の添加，あるいはアニールによるアクリ 
ル系エラストマーブレンド PLA の結晶化がタフネスに及 ぼす影響を検討する。

\section{2. 試料と実験方法}

\section{1 試料および成形方法}

PLA は三井化学(株品（商品名：LACEA H-100, Mw= 12500), アクリル系エラストマーは三菱レイヨン (株)のア クリル系コアーシェル型複合ゴム（商品名：メタブレン W-450 A，ゴム粒子径 100〜300 nm）を用いた。結晶核剤 には日産化学工業(株)のフェニルホスホン酸亜鉛（商品名： エコプロモート, 粒径 $<3 \mu \mathrm{m})$, PLA の分解を抑制する ために日清紡ケミカル(株)のポリカルボジイミド（商品 名：カルボジライト LA-1）を添加した。

PLAに対する結晶核剂および分解抑制剂のブレンド比 率はマトリックスに対し，重量比で $0.5 \mathrm{wt} \%$ とした。ま た，アクリル系エラストマーの添加量は，10，30 wt\%で

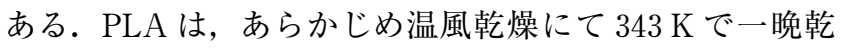
燥させた。ブレンドはウェルナー\&フライデラー社製二軸 押出機を用い, バレル温度 $453 \mathrm{~K}$ から $493 \mathrm{~K}$ で溶融混練し た。スクリュー回転数は $250 \mathrm{rpm}$, 吐出量は $2 \mathrm{~kg} / 10 \mathrm{~min}$ である。

ダンベル型, そして矩形の試験片は, 型締力 $120 \mathrm{t}$ の (株) 名機製作所製射出成形機（NADEM-1200）を用いて，バ レル温度 $483 \mathrm{~K}$, 金型温度 $308 \mathrm{~K}$ および $373 \mathrm{~K}, 1$ サイク ル $47 \mathrm{sec}$ で作製した。

核剤の添加により PLA を結晶化させるための金型温度 は $373 \mathrm{~K}$ とした. 金型温度を $308 \mathrm{~K}$ に設定して成形された PLA は非晶構造を持つ.この試料を結晶化させるために， 成形後の試験片を $373 \mathrm{~K}$ の温風乾燥機を用いて, $60 \mathrm{~min}$ アニールを行った. また処理中の試験片の熱変形を防ぐた めに, 試験片の寸法に合わせて切削したアルミ板の型に試 験片を置き，同じくアルミ板で蓋をした．試料のブレンド 条件を表 1 に示す.

\section{2 実験方法}

\subsubsection{U 字型切欠き試験片によるタフネスの評価}

射出成形した長さ $130 \mathrm{~mm}$, 幅 $10 \mathrm{~mm}$, 厚さ $5 \mathrm{~mm}$ の矩 形片からタフネスを評価するために機械加工により U 字 型切久き試験片を作製した。 U 字型切欠き試験片は長さ $50 \mathrm{~mm}$, 幅 $10 \mathrm{~mm}$, 厚さ $5 \mathrm{~mm}$ である. U 字型切欠きの 先端半径は $0.5 \mathrm{~mm}$, 切欠き部の試料の厚さ, 言い換える とリガメントの厚さは $3.5 \mathrm{~mm}$ である. 切欠きは外丸フラ イスを用いて作製した. なお機械加工においては試料の温 度の上昇によって切欠き部の先端が大きく塑性変形し, 残 留ひずみが生じることを防止するために試料を水で冷やし

Table 1 Composition and Condition of blends

\begin{tabular}{c|c|c|c|c}
\hline \multirow{4}{*}{ Composition } & $\begin{array}{c}\text { Elastomer } \\
\text { (Acrylic elastomer) }\end{array}$ & wt $\%$ & $0,10,30$ & $0,10,30$ \\
\cline { 2 - 5 } & $\begin{array}{c}\text { Hydrolysis Stabilizer } \\
\text { (Polycarbodiimide) }\end{array}$ & $\mathrm{wt} \%$ & 0.5 & 0.5 \\
\cline { 2 - 5 } & $\begin{array}{c}\text { Nucleus Agent } \\
\text { (Phenyl Zinc Phosphonate) }\end{array}$ & $\mathrm{wt} \%$ & - & 0.5 \\
\hline \multirow{3}{*}{ Condition } & Mold Temperature & $\mathrm{K}$ & 308 & 373 \\
\cline { 2 - 5 } & Anneal Treatment & - & $\begin{array}{c}373 \mathrm{~K} \\
60 \mathrm{~min}\end{array}$ & - \\
\hline
\end{tabular}

つつ出来るだけ低速で加工を行った.

タフネスはU 字型切欠き試験片による三点曲げ試験の 変位一曲げモーメント曲線により評価した。変位一曲げ モーメント曲線は(侏)島津製作所島津オートグラフ $(\mathrm{AG}-500$ E）を用いてスパン間の長さ（支点間距離） $40 \mathrm{~mm}$ で三点 曲げ試験により評価した。試験温度は $296 \mathrm{~K}$, 曲げ速度 2 $\mathrm{mm} / \mathrm{min}$ である.

\section{2 .2 降伏応力の評価}

公称応力一ひずみ曲線は島津オートグラフ $(\mathrm{AG}-500 \mathrm{E})$ にて, 厚さが $1 \mathrm{~mm}$, 幅が $6 \mathrm{~mm}$, 平行部の長さが $20 \mathrm{~mm}$ のダンベル型試験片を用いてひずみ速度 $0.1 / \min$ の一軸

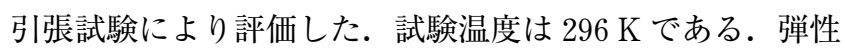
率と降伏応力はこの応力ーひずみ曲線から推定した。

\section{2 .3 真応力一ひずみ曲線の評価}

脆性的な PLA の大きなひずみまでの応力ーひずみ曲線 を一軸引張試験により評価するのは困難である。異なる結 晶化の方法で作製した試料の大きなひずみまでの真応力一 ひずみ曲線の評価のために，ダイスによる平面ひずみ圧縮 試験を行った. ダイスの幅は $6 \mathrm{~mm}$, 長さ $10 \mathrm{~mm}$, 試験片

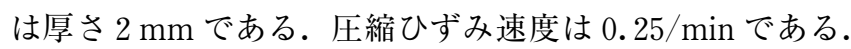
これらの力学試験には島津オートグラフ $\left(\mathrm{AG}^{-}-5 \mathrm{kNE}\right)$ を 用いた。

\subsubsection{U 字型切欠き部先端での塑性領域のモルフォロ ジーの解析}

$\mathrm{U}$ 字型切欠き試験片の切欠き先端の変形と塑性領域の モルフォロジー解析のためひずみを固定するための曲げ冶 具（支点間距離 $40 \mathrm{~mm}$ ）を用いて変形させた. 負荷を除 くことによるひずみの回復によって変形領域の形態の変化 をできるだけ防ぐために，負荷を加えた状態でエポキシ樹 脂を流し込むことでひずみを固定した。ひずみを固定した 試料は, 変形状態の塑性領域からミクロトームにて切片を 切り出し光学顕微鏡で観察した. ひずみの固定に用いたエ ポキシ樹脂はシェル 820, 硬化剤は発熱の小さいアンカマ イドである. 硬化剤はエポキシ樹脂 100 重量部に対して 60 重量部で混合した.

\subsection{5 動的粘弾性測定による耐熱温度の評価}

弾性率の温度依存性はレオメトリックス社製の動的粘弾 性装置（RSA-II）を用い，303〜 403 K の温度範囲で周波 数 $10 \mathrm{~Hz}$, 昇温速度 $2 \mathrm{~K} / \mathrm{min}$ の条件下で一軸引張試験によ り評価した。

\subsection{6 結晶化度の評価}

結晶化度の測定は Rigaku 社製 X 解回折装置（MicroMax 007）を用いて X 線回折から評価した。単色化 $\mathrm{CuK} \alpha$ 線を用い, 波長は $1.5418 \AA$, 出力は $40 \mathrm{kV}, 20 \mathrm{~mA}$, コリ メーターは $0.2 \mathrm{~mm} \phi$ である。照射時間は $180 \mathrm{sec}, 0 \sim 45$ 度である。

\section{3. 実験 結 果}

\section{1 三点曲げ試験によるタフネスの評価}

図 1 に金型温度の相違がタフネス（変位一曲げモーメン 卜曲線）に及ぼす効果を示す。核剤を添加し，金型温度 $373 \mathrm{~K}$ で成形した試料は, 全てのアクリル系エラストマー の添加量において $308 \mathrm{~K}$ で成形した試料よりもタフネスが 低いことが分かる. 
図 2 に異なる結晶化の方法が夕フネスに及ぼす影響を示 した。図 1 と同様にアクリル系エラストマーを添加すると タフネスが向上することがわかる．金型温度 $373 \mathrm{~K}$ および アニールにより結晶化したブレンド PLA のタフネスを比 較すると，アクリル系エラストマーの添加量が $0,10 \mathrm{wt}$ \%ではアニールによって結晶化させたブレンド PLA の方 が優れていることがわかる.アクリル系エラストマー添加 量が $30 \mathrm{wt} \%$ では夕フネスはほぼ同程度であった。

\section{2 変形による $\mathrm{U}$ 字型切欠き部先端の塑性領域}

図 3 は光学顕微鏡による曲げ試験片の切欠き先端に形成 された塑性領域を示す。アクリル系エラストマーの $10 \mathrm{wt}$ \%ブレンドにより金型温度 $308 \mathrm{~K}(\mathrm{a}) ， 373 \mathrm{~K}(\mathrm{~b})$ (核剤添 加）いずれの成形試料において，破断までに大きな塑性領 域が形成されることが分かる．塑性変形は，ソフニング由 来と推測される不均一変形であり ${ }^{10)}$, また (a) は (b) と比較 して塑性領域の拡張の度合いが大きく，より安定した塑性 変形をしている.

\section{3 耐熱温度の評価}

図 4 に動的粘弾性測定によるPLA の貯蔵弾性率および 損失弾性率 $(\operatorname{Tan} \delta$ ) の温度依存性を示す。金型温度が 308

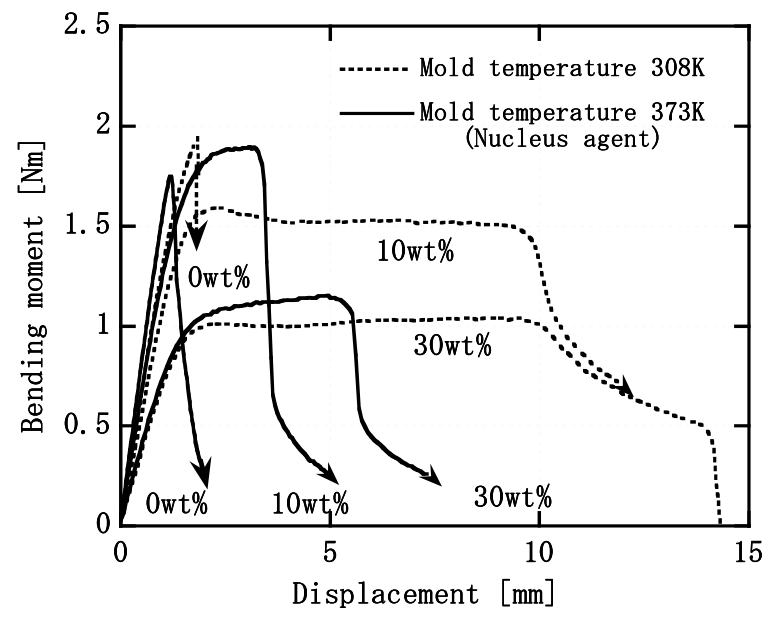

Fig. 1 Effect of crystallization due to the addition of nucleus agent on the toughness (bending moment-displacement curves) of modified PLA

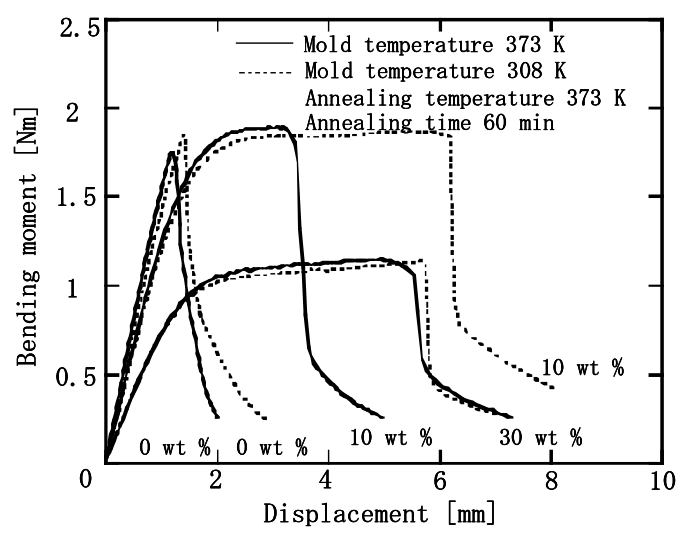

Fig. 2 Effect of crystallization arising from annealing at temperature of $373 \mathrm{~K}$ on the toughness of modified PLA in comparison with that of modified PLA crystallized by the addition of nucleus agent
$\mathrm{K}$ および $373 \mathrm{~K}$ のどちらも $333 \mathrm{~K}$ 付近にガラス転移温度が 発現している. 金型温度 $308 \mathrm{~K}$ の試料は $333 \mathrm{~K}$ 付近から急 激に貯蔵弾性率の低下が見られるが, 金型温度 $373 \mathrm{~K}$ の場 合その程度が $308 \mathrm{~K}$ と比較して緩やかでありその值も高く, 耐熱温度の向上が見られる. 金型内で結晶化が促進された めと言える．大きさは異なるがアクリル系エラストマーを ブレンドしたPLAにおいても同様な結果が得られている.

\section{4 結晶化度の評価}

図 5 に X 線回折の回折像および計算から算出した結晶 化度を示す．金型温度 $308 \mathrm{~K}$ で成形しブレンド PLA の結 晶化度は，およそ $1 \%$ とほとんど非結晶状態であるのに
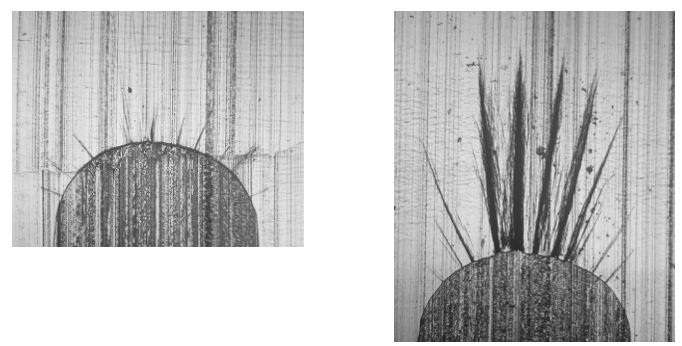

Modifier 0wt\%

$10 \mathrm{wt} \%$

(a) Mold temperature $308 \mathrm{~K}$
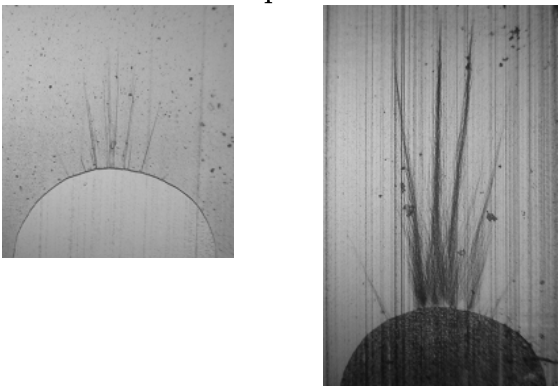

Modifier 0wt\%

$10 \mathrm{wt} \%$

(b) Mold temperature 373K

$0.5 \mathrm{~m} \mathrm{~m}$

Fig. 3 Effect of crystallized conditions on the morphology of plastic deformation of the modified PLA at the tip of notch

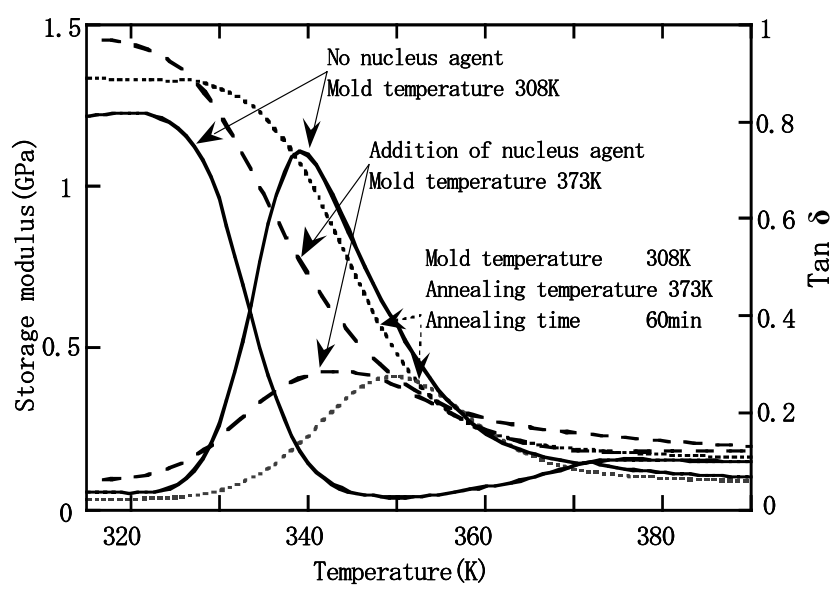

Fig. 4 Effect of crystallization on the temperature dependence of both dynamic storage modulus and loss modulus $(\tan \delta)$ of PLA 
対し，金型温度 $373 \mathrm{~K}$ およびアニールにより結晶化した試 料はそれぞれ $36.1 \%$ および $40.7 \%$ と結晶化が進行してい る.アニールにより結晶化した試料がより結晶化度が高い. いずれの回折像からは不均一な同心円状のピークが見られ， 幾分配向していることがわかる. 金型温度 $373 \mathrm{~K}$ の試料は 小角側に若干のピークが認められることからアニール試料 に比べ大きな構造，ここでは球晶ができていることが予想 される。

\section{5 降伏応力の評価}

図 6 に一軸引張試験によるPLA の公称応力一ひずみ曲 線を示す. 金型温度 $308 \mathrm{~K}$ で成形された非晶 PLA の降伏 応力が最も低い. 核剂を添加し, 金型温度 $373 \mathrm{~K}$ での成形, そして金型温度 $308 \mathrm{~K}$ で成形その後 $373 \mathrm{~K}$ のアニールによ り結晶化させることにより降伏応力は増加し, また剛性も 高くなった. 最も剛性が高いのは金型温度 $373 \mathrm{~K}$ で成形し たPLAである。これに対して破断ひずみは金型温度 373

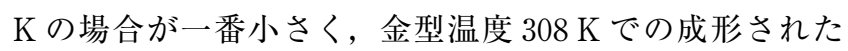
PLA はそれに比較して破断ひずみは大きい, 最も破断ひ ずみが大きいのはアニールによって結晶化したPLAで あった。この結果は, 成形時に結晶化させるとタフネスは 低下するのに対し，アニールにより結晶化すると，より安 定した変形が可能なことを示唆している.

\section{6 真応力一ひずみ曲線の評価}

図 7 に圧縮試験による真応力一対数ひずみ曲線を示す. 金型温度 $308 \mathrm{~K}$ で成形した試料には降伏後の応力の低下で あるソフニングが見られるが, 金型温度 $373 \mathrm{~K}$ および

No Nucleus Agent

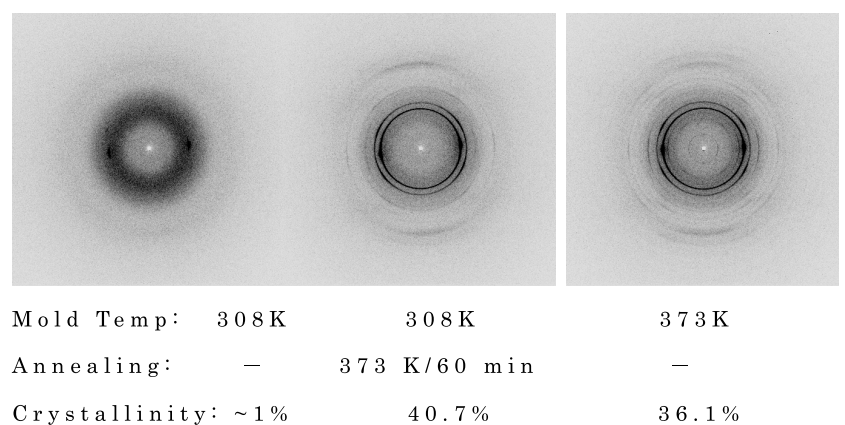

Fig. $5 \mathrm{X}$-ray diffraction patterns of PLA crystallized by the differing crystallized conditions and the crystallinity calculated from these patterns

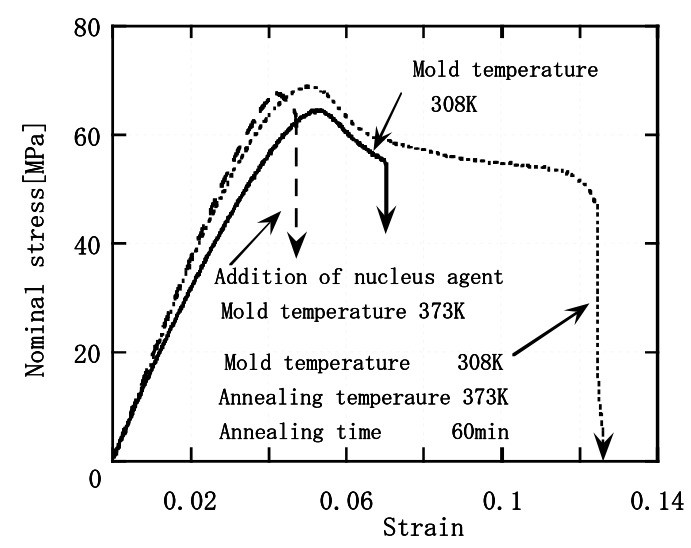

Fig. 6 Effect of crystallization on the stress-strain curves measured by the uniaxial tensile test
ニールにより結晶化した試料にはそれは見られない。また これらの結晶化した試料の降伏応力は金型温度 $308 \mathrm{~K}$ と比 較して高い.

一方ハードニングの速度は, 金型温度 $308 \mathrm{~K}$ で成形ア ニールした試料が一番大きく, 金型温度 $308 \mathrm{~K}$ 試料と 373 $\mathrm{K}$ 試料とともにほぼ同等の速度となった.

\section{4. 考察}

高分子材料の脆性破壊は, 破壊の前駆体であるクレイズ を構成するフィブリルの切断により起こる. 一般にクレイ ズ強度は数平均分子量に比例して増加する. 局所的な塑性 変形に伴う応力集中の大きさは降伏応力に依存し, 高い降 伏応力は大きな応力集中を導くので, 最大応力がクレイズ 強度に達しやすくなり, 結晶化の進行はタフネスの低下を 導くことが知られている ${ }^{11}$. それはエラストマーを添加し, タフネスの向上を図った場合でも同様である.

エラストマーを添加すると, 系全体の弾性率の低下, エ ラストマー周辺部の応力集中に伴う可塑化による降伏応力 の低下，およびエラストマーのボイド化に伴うひずみの拘 束の解放による系全体の応力の抑制という系の変形を安定 化させる三つの効果がある。

ボイド化により, 系にかかる応力が抑制され系の変形は 安定化に向かうが, 必ずしも系の変形が安定化するわけでは ない. 高分子材料の構造とそのときの応力状態に依存する. 脆性破壊の前駆体であるボイドとフィブリルから構成さ れるクレイズは, 膨張応力により発生したボイドが拡張す る際に塑性不安定条件を満足したときに形成される ${ }^{12}$. ボ イドが不安定に拡張する条件はボイドの密度とハードニン グの速度に依存する．図 8 はこのボイドを含む塑性領域の 安定性の概念を示した. ボイドが膨張応力による塑性変形 によって拡張するとき, ボイドの拡張にともなって系に蓄 えられた弾性ひずみエネルギー $\left(\partial \mathrm{U}_{\mathrm{E}} / \partial \mathrm{V}\right)$ の変化速度が ボイドの拡張によって費やされる塑性ひずみエネルギー $\left(\partial \mathrm{U}_{\mathrm{P}} / \partial \mathrm{V}\right)$ の変化速度より式 (1)に示すように

$$
\frac{\partial U_{P}}{\partial V} \leq \frac{\partial U_{E}}{\partial V}
$$

大きいとき，系に蓄えられた弾性ひずみエネルギーが自発 的に塑性ひずみの増加をもたらしボイドの不安定な拡張が 起こり, それがクレイズとなる. 負荷の大きさ, あるいは

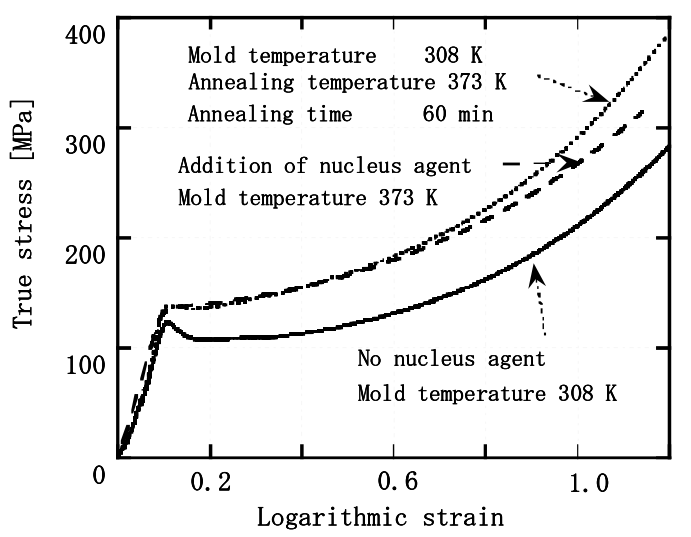

Fig. 7 True stress-strain curves of both amorphous and crystallized PLA 
ボイドの密度が小さいときにはこの条件は満足されず，変 形は安定であるが，ひとたび上記の条件に到達すると，外 からのひずみあるいは応力の制御により変形を制御するこ とは不能になり，ひずみは急速に局所的に集中を起こす。 金属ではこのような塑性不安定が起きると，ボイド間が滑 り切りを起こすので脆性的な破壊となる.

一方，樹脂のハードニングが十分に大きい場合，塑性変 形に伴うエネルギーが大きいので条件

$$
\frac{\partial U_{P}}{\partial V} \geq \frac{\partial U_{E}}{\partial V}
$$

を満足して，ボイドの拡張に伴う塑性変形のエネルギー変 化速度が弾性ひずみエネルギーのそれより大きく成る。こ のときひずみの集中化は抑止され安定にボイドは拡張し，

不安定な破壊は抑制される.

\section{1 結晶化した PLA の力学特性と耐熱性}

図 4 の弾性率の温度依存性と図 5 の結晶化度から, 結晶 化度の増加は PLA の剛性を上昇させ，高温まで高い弾性 率を維持し耐熱性を向上することを示している．また図 6 の一軸引張応力ーひずみ曲線は結晶化すると降伏応力が増 加することを示している.

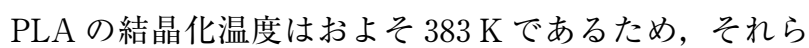
近傍の温度で結晶化することによって結晶化度は増加する。 結晶化度の増加は, 一般に結晶を構成するラメラ結晶の厚 さが増加する，その結果，負荷をかけたときに結晶の厚さ 方向である C 軸の滑りに対する抵抗が大きくなるので降 伏応力は増大する. 金型温度 $308 \mathrm{~K}$ で成形した PLA は, X 線回折の結果からほぼ非晶状態である.

一軸引張応力試験である図 6 において, 金型温度 $308 \mathrm{~K}$ の試料とそれをアニールした試料を比較すると，アニール 試料は結晶化により降伏応力が増大するので, 低伸度でク レイズ強度に達し脆性的に破壊すると予想されるにも関わ らず，伸度が大きい結果となっている.

圧縮試験である図 7 において非晶構造の PLA は降伏後 の応力の低下であるソフニングが見られるが，アニールお よび金型温度 $373 \mathrm{~K}$ で結晶化した PLA は降伏応力が増加 し，またソフニングは認められなくなっている.

ソフニングは塑性変形部に扔ける変形が局所的に不安定 化し変形が集中する現象であるが, 変形中に安定化が起こ
らない限り脆性的に破壊する。一軸引張試験である図 6 の 場合, 結晶化していない PLA がこれに相当し脆性的に破 壊する。一方，アニールにより結晶化させたPLA は，高 い降伏応力を持つ微結晶が塑性変形を安定化する，別な言 い方をすると局所変形の伝播を阻害しソフニングを抑制す ると推定する.

\section{2 結晶化条件の影響}

図 2 においては, 結晶化させた金型温度 $373 \mathrm{~K}$ 試料とア ニール試料の差は小さいが，エラストマー添加量が $10 \mathrm{wt}$ \%の場合，有意な差が認められる。

エラストマーの添加のない非晶状態である金型温度 308 $\mathrm{K}$ 試料は, 図 1 のように脆性破壊することから, 結晶化し た金型温度 $373 \mathrm{~K}$ 試料とアニール試料も，エラストマーを 添加しない場合，図 2 のようにいずれも脆性破壊して差が 認められない。一方，エラストマー添加量が $30 \mathrm{wt} \%$ と多 い系では先に述べたエラストマーの三つの効果が顕著とな るため, 系の応力が大きく低下して系に蓄えられる弾性エ ネルギーが抑制されるので，金型温度 $373 \mathrm{~K}$ 試料とアニー ル試料ともに結晶化しているにもかかわらず安定的に破壊 が進行し延性破壊となり差が認められなくなる。

以上からエラストマー添加量が $10 \mathrm{wt} \%$ の系は，脆性破 壊と延性破壊の転移領域とみなすことができる。このよう な転移領域に打いては，結晶構造に由来する高次構造の違 いが顕著になり，金型温度 $373 \mathrm{~K}$ 試料とアニール試料の差 が大きくなったと考える.

図 7 の真応力ーひずみ曲線は, アニールによって結晶化 した PLA のハードニングの速度が金型温度 $373 \mathrm{~K}$ での結 晶化したPLAのそれよりも大きいことを示している。こ れはアクリル系エラストマーから形成されたボイドの密度 が同じであればアニールによって結晶化した PLA は大き なひずみまで安定して変形することを意味する.

タフネス拉よびハードニングは結晶化により形成された 構造に依存すると考えることは妥当と思われる.

結晶核剤を添加し結晶化温度付近の金型温度で成形した 場合，結晶はその核剤から成長を開始する．図 9 にそのモ デルを示す．成長する結晶は熱運動により活発に分子運動 をしている分子鎖を結晶にたぐり寄せる（図 $9(\mathrm{a}))$ 。この 溶融状態に扔ける絡み合いは，結晶化のために絡み合いが ほどける方向に分子運動するものと考える. その結果, 図

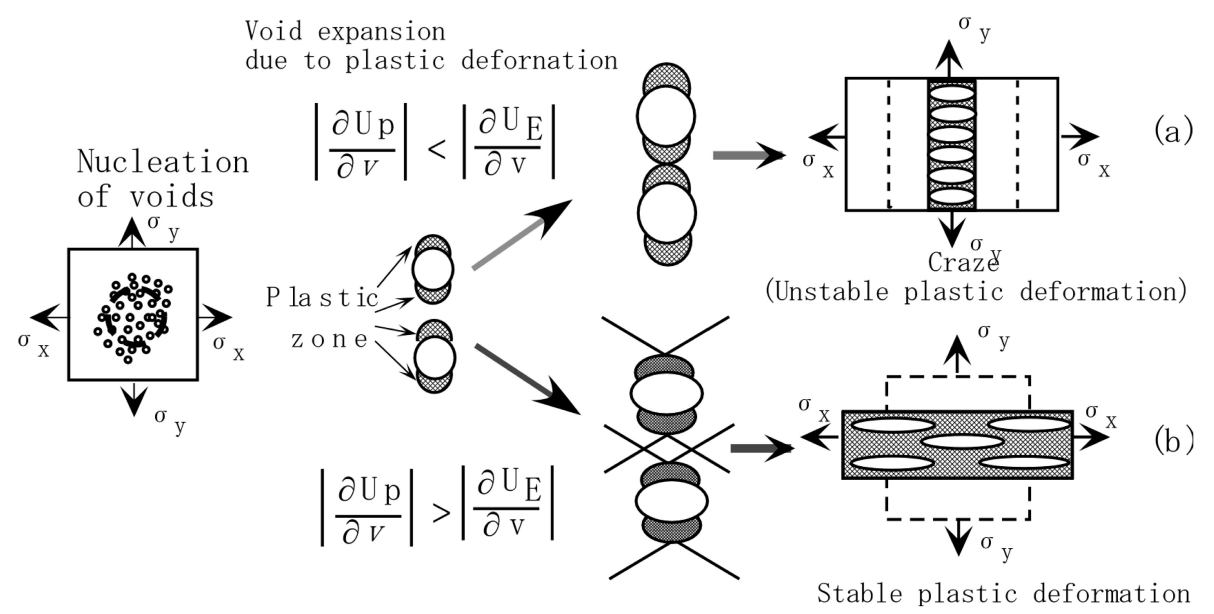

Fig. 8 Illustration of plastic deformation instability for void expansion 
5 から若干の配向がかかっているものの結晶核剤を中心に 等方的に成長した結晶化度 $36.1 \%$ の微結晶と絡み合い密 度の小さい非晶部とからなる球晶構造になっているものと 推定する。

一方，結晶核剤無添加で，金型温度 $308 \mathrm{~K}$ で成形された PLA を $373 \mathrm{~K}$ で 60 分間アニールした場合, 試験片表層か ら温度が上昇し内部に伝わる。アニールによる分子鎖の局 所的な拡散運動により結晶化が起きるとき, 溶融結晶化の 場合とは異なり, 内部は表層より温度が低いので分子鎖の 動きが拘束された状態で結晶化が進み, 絡み合いがほどけ る可能性は低いと推測される (図 $9(\mathrm{~b}))$. その結果, 若干 配向がかかり不規則であるが等方的な微結晶の集合と絡ま り密度の高い非晶部とからなる構造になっているものと推 定する.

\section{3 試験片形状の影響}

図 6 の破断ひずみの関係とは異なり, 図 1 と図 2 の比較 では，金型温度 $308 \mathrm{~K}$ 試料の方が，アニール試料よりも夕 フネスが高い。これは試験片の形状が異なるためと考えら れる. 図 1,2 の曲げモーメント曲線は切欠き部におけ る応力状態を反映している。試験片の幅と厚みが大きいの で，切欠き部においては，ひずみの拘束による膨張応力が 大きくなり降伏後の塑性変形は抑制される方向にある。さ らにアニール試料や金型温度 $373 \mathrm{~K}$ 試料のように結晶化す ると, 結晶部がひずみの拘束点となり塑性変形の伝播を阻 害することから, 試験片形状によるひずみの拘束に結晶化 によるひずみの拘束が加わり塑性変形が更に抑制されるこ とになる. 弾性エネルギーとして蓄積され応力が急激に増 加しつつ塑性変形が進展することになるが, 応力が破断強 度に到達すると弾性エネルギーの緩和とともに亀裂が進展

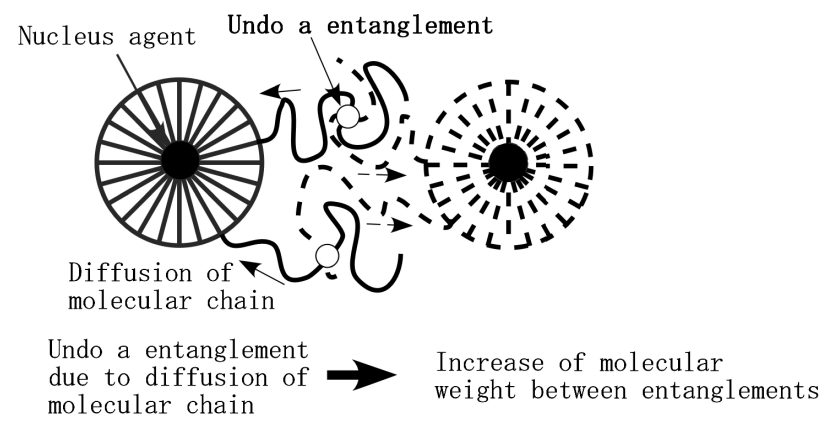

(a) Addition of nucleus agent

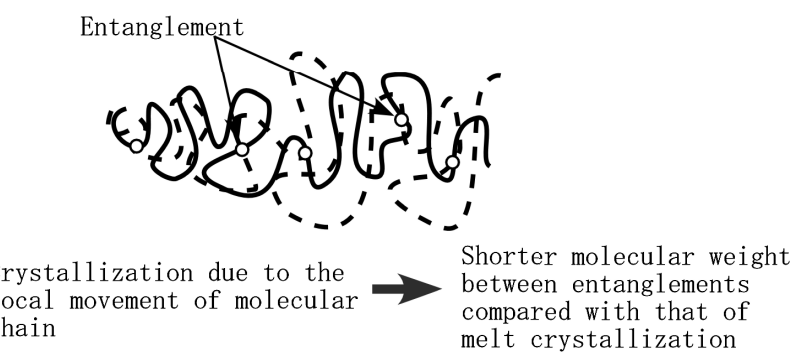

(b) No nucleus agent

Fig. 9 Schematic representation of molecular weight between entanglements due to the condition of crystallization
し脆性破壊するものと考える.

それに対して結晶化していない金型温度 $308 \mathrm{~K}$ 試料は, 切欠きがなく厚みのない引張試験の場合, 変形部では, ひ ずみの拘束が小さいため塑性変形に対する抵抗も小さくな り，弾性ひずみエネルギーが蓄積されることなく緩和され 図 6 に示すように脆性的に破壊すると考える。一方, 切欠 きを有する曲げモーメントの測定では，応力が集中する切 欠き部で変形が進展するが, そこでは試験片形状由来のひ ずみの拘束が塑性変形の抵抗となり, 弾性エネルギーの蓄 積と緩和をバランスさせ図 1 に示すように系の変形を安定 化したと思われる。

\section{5. 結 論}

結晶核剤を添加して射出成形時に高温金型内で結晶化さ せた場合のタフネスと結晶核剤を添加せずに低温金型で成 形後アニール処理により結晶化させた場合のタフネスを比 較検討した。

結晶化により，耐熱性は向上し，またアクリル系エラス トマーを添加した系は, 非晶状態の場合より程度は小さい がタフネスも向上することがわかった.

非晶状態からアニールによって結晶化させた試料の方が， 結晶核剂を添加して射出成形時に高温金型内で結晶化させ た試料より優れたタフネスを発現することがわかった。ま た結晶化の条件によって圧縮試験におけるハードニングに 違いが認められた。このハードニングの違いが夕フネス発 現性に影響していると推定した。

\section{参 考 文 献}

1 ) Avella, M., Emanuela, M., Immirzi, B., Falcigno, L. and Paolillo, L. : Macromol. Chem. Phys., 201, 1295 (2000)

2 ) Weir, N. A., Buchanan, F. J., Orr, J. F., Farra, D. F. and Boyd, A. : Biomaterials, 25, 3939 (2004)

3 ) Martin, O. and Averous, L. : Polymer, 42, 6209 (2001)

4 ) Sugimoto, M., Hatada, K. and Ishikawa, M. : Polymer, 36, 3675 (1995)

5 ) Ishikawa, M., Sato, Y. and Higuchi, H. : Polymer, 37, 1177 (1996)

6 ) Ishikawa, M., Ushui, K. and Hatada, K. : Polymer, 37, 1601 (1995)

7 ) Ishikawa, M. and Kobayashi, Y. : Kobunshi Ronbunshu, 52, 141 (1995)

8 ）伊藤公一, 阿部聡美, 石川優：JSPP’07 Tech. Papers, 171 (2007)

9 ) Crist, B., Fisher, C. J. and Howard, P. R. : Macromolecules, 22, 1709 (1989)

10) Ito, M., Abe, S. and Ishikawa, M. : J. Appl. Polym. Sci., 115, $1454(2010)$

11) Argon, A. S. : Phil. Ma., 28, 829 (1973)

12) Argon, A. S. : The Solid State of Polymers (Ed. P. H. Geil, E. Bear and Y. Wada), 573 (1974), Marcel Dekker 